\title{
NUTRITIVE POTENTIAL OF SOME BROWSE PLANTS GROWN UNDER THE EGYPTIAN DESERT CONDITIONS \\ AbdEI-Rahman,H.H. ${ }^{*}$; A.M.Kandil**; Fatma M. Salman ${ }^{\star}$ and M. I. Mohamed \\ * Dept. of Animal Production, National Res. Center, Dokki, Giza, Egypt. \\ ** Dept. of Animal Production, Fac. of Agric., Al- Azhar Univ., Cairo, Egypt
}

ABSTRACT

Browses plants leaves and stems from Kochia indica, Suaeda vera, Atriplex halimus, Tamarix mannifera, Halocnemum strobilaceum, Lygos raetam, Artemisia monosperma, Hammada elegans, Thymalaea hirsuta, Peganum harmala and Zygophillum album were evaluated for nutritive potential (chemical composition and degradability characteristics). Crude protein (CP), crude fiber (CF), ash, ether extract (EE), neutral detergent fiber (NDF), acid detergent fiber (ADF) and acid detergent lignin (ADL) were determined (on dry matter basis). Mean values of $\mathrm{CP}, \mathrm{CF}, \mathrm{EE}$, ash, NFE, NDF, ADF and ADL for shrub species tested were 9.8\%, 23.23\%, 2.95\%, $22.71 \%, 41.53 \%, 50.07 \%, 32.65 \%$ and $10.46 \%$, respectively. Crude protein content ranged from $5.9 \%$ (Z.album) to $20.0 \%$ (P.harmala). Kochia indica and L.raetam had moderate CP content $14.0 \%$ and $10.5 \%$, respectively). Zygophillum album had lowest NDF, ADF and ADL $(30.2 \%, 18.3 \%$ and $3.5 \%)$, respectively comparable to $A$. halimus $(63.5 \%, 43.9 \%$ and $13.8 \%)$, respectively.

The content of macrominerals such as phosphorus $(P)$, sodium $(\mathrm{Na})$, calcium $(\mathrm{Ca})$ and potassium $(\mathrm{K})$ was also determined. In addition, manganese $(\mathrm{Mn})$, Zinc $(\mathrm{Zn})$, copper $(\mathrm{Cu})$, iron $(\mathrm{Fe})$ and magnesium $(\mathrm{Mg})$ were measured as microminerals content. The shrubs showed varied values of macro and micro minerals content.

In Vitro dry matter (DM) and organic matter (OM) degradability showed that $K$. indica, $S$. vera and $H$. strobilaceum had the highest values of DM and OM degradability $(67.87 \%$ and $65.37 \% ; 65.53 \%$ and $61.0 \% ; 64.27 \%$ and $62.73 \%$, respectively), compared with $Z$. album, $T$. hirsuta and $P$. harmala that had the lowest values $(47.27 \%$ and $45.50 \% ; 47.13 \%$ and $44.50 \%$; 44.33 and $46.87 \%$, respectively)

The secondary metabolites, which are considered anti-nutritional defenses against grazing animals such as saponins, alkaloids, flavonoids, sterols, tannins and coumarine were analyzed qualitatively and were expressed as an indicator to their presence in these plants. The results showed that the tested plants varied in their contents of anti-nutritional factors.

Keywords: Browse plants, Chemical composition, Degradability characteristics, Antinutritional factors.

\section{INTRODUCTION}

Egypt is classified as a semi-arid country since it is characterized by winter rain fall varies from less than 150 to $250 \mathrm{~mm}$ year and dry summer. The irrigated valley represents $4 \%$ of its land while the rain fed desert represents $96 \%$. In these desert regions halophytic plants often dominate, few of them plants are palatable (30\%- $40 \%)$. Unpalatable halophytes are distribute and represent about $60 \%$ - $70 \%$ of natural rang land vegetation in Egyptian desert. These plants are resistant to salinity and drought conditions. The name halophyte does not designate a number of any particular taxon or any specific geographic or physiographic area. The word literally means "salt plant" and is used to referee to any plant that is capable of growing and 
reproducing in areas subject to high salinity is somewhat subjective, but most people consider a salinity equivalent to about $0.5 \% \mathrm{NaCl}$ in the soil water as a rough approximation of the lower of the salinity range. This corresponds to a concentration of around $85 \mathrm{~m} \mathrm{M} \mathrm{NaCl}$. Thus, it may appear easy to designate these plants that deserve the name halophyte (James and Edward, 1994).

Halophytes occupy important niches in many (particularly arid) ecosystems. This is due to the ease with which they adapt to many diverse and generally harsh environments (Chapman, 1974). Halophytic plants play a significant role in ruminant nutrition. Halophytes species because of their resistance to heat, drought, salinity, alkalinity, drifting sand, grazing and repeated cutting, are the major advantage during the dry season (Fagg and Stewart, 1994), However, due to the presence of secondary plant metabolites (particularly tannins) in halophytes, the utilization of protein and organic matter in these feeds is low (Waghorn and Shelton, 1997).

The object of the present study is to evaluate the chemical composition and degradability characteristics of some natural desert range plants.

\section{MATERIALS AND METHODS}

This study was conducted at the experimental farm and Laboratories of National Research Centre, Giza, Egypt.

Range plants naturally grown in with relatively high biomass in Sinai Peninsula, Nubaria desert and North Western Cost of Egypt were collected during the green season of each plant, chemically analyzed. Investigated plants were Kochia indica, Suaeda vera, Atriplex halimus, Tamarix mannifera, Halocnemum strobilaceum, Lygos raetam, Artemisia monosperma, Hammada elegans, Thymalaea hirsuta, Peganum harmala and Zygophllum album.

Samples of succulent parts (leaves and stems) of each plant were air dried separately on thin plastic sheet to avoid mechanical losses or sand contamination.

Proximate analysis and minerals were determined according to A.O.A.C. (1996) procedures. Goering and Van Soest (1970) methods were used to determine cell wall constituents (CWC).

In vitro $D M$ and $O M$ disappearance

In vitro dry matter (IVDMD) and organic matter (IVDMD) disappearance were determined for the halophytic plants according to Tilley and Terry (1963) modified by the method of Norris et al. (1976) in triplicate dried and ground samples. Animals were maintained on berseem hay (Trifolium alexandrinum) for a period of at least 3 weeks before collecting the rumen liquor. Hay was offered to animals at the rate of $150 \%$ of maintenance requirements in two equal meals mainly at 08:00 a.m. and 17:00 p.m.

\section{Qualitative phytochemical screening}

The phytochemical screening of some secondary metabolites was carried out on the dried plants. 
The experimental plants used in this study contained variable secondary metabolites according to their species. The results of qualitative analysis was expressed by $(-,+,++,+++)$ signs. The materials have $(-)$ sign express nil values, while the $(+,++,+++)$ signs expressed the presence of these materials. The number of $(+)$ signs detect the expected amounts of these materials.

Tannins

About $5 \mathrm{~g}$ sample was extracted with diluted ethanol (50\%) and filtered. To $5 \mathrm{ml}$ of each extract, ferric chloride (T.S) was added. An olive green colour was developed in case of positive tannin (Wall et al., 1954).

Saponins

Froth test: About $2.5 \mathrm{~g}$ sample of each material were extracted with boiling water. After cooling the extract was shacked vigorously until froth was obtained then allowed to stand for 15-20 minutes (No froth = negative (-), froth less than $\mathrm{Icm}$ high $=$ weakly positive $(+)$, froth $1-2 \mathrm{~cm}$ high $=$ positive $(++)$, froth greater than $2 \mathrm{~cm}$ high $=$ strongly positive $(+++)$ (Gihad et al., 2003).

\section{Alkaloids}

The alcoholic extract of $2.5 \mathrm{~g}$ plant material was concentrated, taken up with $0.5 \mathrm{ml} 10 \%$ hydrochloric acid and filtrated. The filtrate was tested for presence of alkaloids using Mayer's and Wanger's reagents (Wall et al., 1954).

\section{Coumarins}

About one gram sample of each plant material was placed in test tube covered with filter paper moistened with diluted sodium hydroxide. The tube was placed in a boiling water bath for few minutes. The filter paper was then removed and examined in UV light (Kingharm and Evans, 1974).

\section{Glycosides and/ or carbohydrates}

About one gram sample of each material was separately extracted with $5 \mathrm{ml}$ of ethanol (50\%). About $0.5 \mathrm{~m} 1$ of alcoholic $\alpha$-naphthol solution was added to each of the alcoholic extracts and sulfuric acid was carefully poured on the wall of test tube to form a separate lower layer. A violet zone was developed at the junction of the two liquids indicating the presence of carbohydrate and or glycosides (Vogel, 1956).

\section{Unsaturated sterols and/ or triterpenses}

The alcoholic extract of $1 \mathrm{~g}$ plant material of each sample was evaporated. Residue was treated with anhydrous chloroform $(10 \mathrm{ml})$ and filtered. The filtrate was divided into 2 portions and tested by Libermann Burchardt and Salkowiski's reactions (Schmidt, 1964).

\section{Libarmann-Burchard test}

To the first portion, $1 \mathrm{ml}$ of acetic anhydride was added followed by $2 \mathrm{ml}$ of $\mathrm{H}_{2} \mathrm{SO}_{4}$ down the walls of the test tube. Rddish-violet ring was produced at the junction of the two layers and then the solution become bluish-green in colour in the acetic layer, indicating the presence of unsaturated sterols and or triterpenes. 


\section{Salkowiski's test}

To the second portion one equal volume of sulfuric acid was added, a red colour was produced, indicating the presence of unsaturated sterols and or triterpenes (Schmidt, 1964).

\section{Flavonoids (Shinoda test)}

Five $\mathrm{ml}$ of alcoholic extract of each sample were treated with $0.5 \mathrm{ml}$ of $10 \%$ hydrochloric acid and magnesium turning (0.5 gm), (Willstatter, 1914). A red colour was observed in case positive flavonoids test.

\section{RESULTS AND DISCUSSIONS}

The approximated analysis of forage tests are presented in Table (1). The highest CP content was found in P. harmala (20\%) followed by $K$. indica (14\%). The other tested forages contained fluctuating values of CP which ranged between (5.9-10.5\%) and the lowest content of CP was found with $Z$. album plant.

Table (1): Chemical composition of some shrubs grown in Egyptian desert (DM \%).

\begin{tabular}{|l|c|c|c|c|c|c|}
\hline Forage species & DM & CP & CF & EE & Ash & NFE \\
\hline Kochia indica & 31.6 & 14.0 & 30.2 & 2.8 & 15.1 & 37.9 \\
\hline Suaeda vera & 31.8 & 8.5 & 29.5 & 1.5 & 20.9 & 39.6 \\
\hline Atriplex halimus & 34.8 & 8.8 & 25.7 & 2.4 & 31.0 & 32.1 \\
\hline Tamarix mannifera & 40.0 & 8.9 & 17.9 & 1.8 & 24.7 & 46.7 \\
\hline Halocnemum strobilaceum & 55.0 & 6.5 & 14.5 & 2.5 & 39.4 & 37.1 \\
\hline Lygos raetam & 61.56 & 10.5 & 37.9 & 2.5 & 14.4 & 34.7 \\
\hline Artemisia monosperma & 48.5 & 8.7 & 16.9 & 6.3 & 18.6 & 49.5 \\
\hline Hammada elegans & 24.1 & 7.8 & 16.5 & 3.9 & 24.6 & 47.2 \\
\hline Thymalaea hirsuta & 42.6 & 8.2 & 30.4 & 4.4 & 8.2 & 48.8 \\
\hline Peganum harmala & 34.1 & 20.0 & 16.9 & 2.1 & 19.5 & 41.5 \\
\hline Zygophillum album & 38.0 & 5.9 & 19.1 & 2.3 & 33.4 & 39.3 \\
\hline
\end{tabular}

The herein results agreed with the findings of Wardeh et al., (1990). They found that the preferred plant species of the desert range contained $8.54 \%$ to $14.89 \%$ crude protein such a high protein content would satisfy most of the protein requirement of consuming animals to performer their physiological functions.

The desert plants tested also contained fluctuation values of CF which ranged between $14.5 \%-37.9 \%$. The highest levels of CF were found with $I$. raetam, $T$. hirsuta and $k$. indica compared with $H$. strobilaceum, $H$. elegans and $A$. monosperma, which contain the lowest values.

These results agreed with that obtained by Gihad et al., (2003), who found that the CF content of palatable, less palatable and unpalatable plants ranged between $14 \%-33 \%$.

The desert plants contain moderate values of $\mathrm{EE}$, except $A$. monosperma which showed extremely high value (6.3\%). The other tested forages showed fluctuating values of EE which ranged between $(1.5 \%$ 4.4\%). The high EE contents of $A$. monosperma could be attributed to the high ratio of waxes and essential oils to true fats present in this plant (Wardeh, 1982). 
The tested forages $T$. hirsuta, $L$. raetam and $k$. indica showed lowest values of ash content being $8.2 \%, 14.4$ and $15.1 \%$, respectively. Meanwhile, H. strobilaceum, Z. album and A.halimus showed highest ash content, being $39.4 \%, 33.4 \%$ and $31.0 \%$, respectively. These high values of ash might be due to their high content of salt which could be predicted from the high $\mathrm{Na}$ and $\mathrm{Cl}$ content (Mohamed, 1996).

The cell wall constituents of different tested forages are illustrated in Table (2). The highest content of NDF were found with $A$. halimus and $k$. indica while the lowest content were recorded with $Z$. album and $H$. elegans. $A$. halimus and $L$. raetam showed also the highest values of ADF. The level of ADL content of tested forages ranged between 3.5-13.8\%. these results were agreed with that obtained by Abd El-Rahman (2003).

Mineral Contents:

Table (2): Cell wall constituents of some shrubs grown in Egyptian desert (DM\%).

\begin{tabular}{|l|c|c|c|}
\hline Forage species & NDF & ADF & ADL \\
\hline Kochia indica & 62.8 & 39.4 & 12.0 \\
\hline Suaeda vera & 52.7 & 33.9 & 13.5 \\
\hline Atriplex halims & 63.5 & 43.9 & 13.8 \\
\hline Tamarix mannifera & 47.7 & 31.2 & 12.1 \\
\hline Halocnemum Strobiclaceum & 61.8 & 32.9 & 10.3 \\
\hline Lygos raetam & 53.3 & 42.5 & 11.6 \\
\hline Artemisia monosperma & 42.0 & 33.9 & 10.8 \\
\hline Hammada elegans & 36.6 & 18.6 & 7.1 \\
\hline Thymalaea hirsuta & 58.9 & 35.0 & 12.3 \\
\hline Peganum harmala & 41.3 & 29.6 & 8.1 \\
\hline Zygophillum album & 30.2 & 18.3 & 3.5 \\
\hline
\end{tabular}

The macro and micro minerals content of the tested plants are shown in Table (3). All shrubs had $\mathrm{Na}$ concentration significantly different among species, however, $P$. haramala had the lowest value. While, $A$. halimus, $k$. indica and $H$. strobilaceum had the highest value of $\mathrm{Na}$. Also, all halophytes had $\mathrm{Ca}$ concentration, $Z$. album, T. mannifera and $H$. Strobilaceum had varied the highest content, while $K$. Indica and $A$. halimus had the lowest contents.

Table (3): Macro and micro minerals content (\%) in some browse species grown in Egyptian desert.

\begin{tabular}{|l|c|c|c|c|c|c|c|c|c|}
\hline Item & $\mathbf{P}$ & $\mathbf{C a}$ & $\mathbf{N a}$ & $\mathbf{K}$ & $\mathbf{M n}$ & $\mathbf{Z n}$ & $\mathbf{C u}$ & $\mathbf{F e}$ & $\mathbf{M g}$ \\
\hline Kochia indica & 0.12 & 0.76 & 4.77 & 2.35 & 0.23 & 0.11 & 0.04 & 0.04 & 0.30 \\
\hline Suaeda vera & 0.10 & 1.60 & 2.03 & 1.69 & 0.22 & 0.09 & 0.03 & 0.03 & 1.61 \\
\hline Atriplex halims & 0.14 & 0.81 & 4.03 & 2.41 & 0.19 & 0.08 & 0.03 & 0.02 & 0.46 \\
\hline Tamarix mannifera & 0.11 & 2.19 & 3.27 & 0.88 & 0.50 & 0.05 & 0.02 & 0.05 & 1.47 \\
\hline Halocnemum Strobiclaceum & 0.08 & 2.16 & 4.16 & 1.55 & 0.13 & 0.02 & 0.10 & 0.13 & 0.48 \\
\hline Lygos raetam & 0.14 & 0.76 & 0.19 & 1.27 & 0.15 & 0.01 & 0.03 & 0.02 & 0.27 \\
\hline Artemisia monosperma & 0.22 & 1.15 & 1.09 & 2.00 & 0.12 & 0.04 & 0.08 & 0.03 & 0.25 \\
\hline Hammada elegans & 0.08 & 1.10 & 3.79 & 1.20 & 1.11 & 0.08 & 0.04 & 0.06 & 0.70 \\
\hline Thymalaea hirsuta & 0.07 & 1.48 & 2.28 & 1.09 & 0.91 & 0.06 & 0.03 & 0.34 & 0.32 \\
\hline Peganum harmala & 0.15 & 1.20 & 0.18 & 1.95 & 0.19 & 0.03 & 0.03 & 0.53 & 0.43 \\
\hline Zygophillum album & 0.01 & 2.80 & 2.80 & 0.76 & 0.09 & 0.02 & 0.03 & 0.04 & 1.07 \\
\hline
\end{tabular}


$S$. vera, T. mannifera and $Z$. album had the highest concentration of $\mathrm{Mg}$, while, L.raetam, A. monosperma and K.indica had the lowest contents.

The high $\mathrm{K}$ content in evaluated shrubs could reduce $\mathrm{Na}$ absorption, because it has been reported that elevated dietary $\mathrm{K}$ may decrease ruminal concentration and absorption $\mathrm{Na}$ in ruminant animal (Ramirez et al., 2001).

In this study, all evaluated shrubs had high $\mathrm{K}$ concentrations accept $T$. mannifera and $Z$. album. Similar findings were reported by Ramirez et al., (2001). Moya-Rodriguez et al., (2002) and Carrilla-Soto et al. (2004) who evaluated $\mathrm{K}$ content in browse species growing in arid and semi-arid regions of the world.

Browse species had $\mathrm{P}$ concentrations that were different between species. A. monospema had the highest content. However, $Z$. album, $H$. elegans and $T$. hirsuta had the lowest contents. In this study, high $\mathrm{Ca}$ and low $P$ content in shrubs resulted in an unusual wide range $\mathrm{Ca}$ : $\mathrm{P}$ ratios. However, it appears that browsing small ruminants can sustain these high ratios without being affected on the P metabolism (Ramirez, 1999).

All browse plants showed low $\mathrm{Cu}$ concentration. Low $\mathrm{Cu}$ levels are also reported in shrubs from semi-arid regions (Barnes et al 1990 and Ramirez - Orduna et al. 1998 and 2005).

All tested shrubs contained Fe levels in substantial amount to meet ruminant requirements. Similar findings were reported by Ramirez et al. (2001) and Carrilla- Soto et al (2004).

$H$. elegans and $T$. hirsuta had the highest $\mathrm{Mn}$ content and $Z$. album had the lowest content, it seems that all shrubs had fluctuating values of $\mathrm{Mn}$. Exception of $K$. indica, all evaluated shrubs contained trace amount of $\mathrm{Zn}$. These levels of $\mathrm{Zn}$ were substantial amount to meat ruminant requirements.

Table (4) showed the values of IVDMD and IVOMD of different plants. The results indicated that the highest values were obtained by $K$. indica, S.vera and H.strobilaceum, while, the lowest values were recorded with P.harmala, T.hirsuta and Z. album. The other shrubs recorded fluctuating values.

Table (4): In vitro DM and OM disappearance of some shrubs grown in Egyptian desert.

\begin{tabular}{|l|c|c|}
\hline Item & IVDMD (\%) & IVOMD (\%) \\
\hline Kochia indica & 67.87 & 65.37 \\
\hline Suaeda vera & 65.53 & 61.00 \\
\hline Atriplex halims & 56.73 & 51.40 \\
\hline Tamarix mannifera & 57.87 & 52.87 \\
\hline Halocnemum Strobiclaceum & 64.27 & 62.73 \\
\hline Lygos raetam & 53.00 & 49.03 \\
\hline Artemisia monosperma & 58.77 & 52.70 \\
\hline Hammada elegans & 53.63 & 45.27 \\
\hline Thymalaea hirsuta & 47.13 & 44.50 \\
\hline Peganum harmala & 44.33 & 46.87 \\
\hline Zygophillum album & 47.27 & 45.50 \\
\hline
\end{tabular}


The low value of IVDMD and IVOMD may be attributed to high level of ADL and NDF or the high concentration of minerals of range plants. These results were agreed with that obtained by Allison and Osbourn (1970), who found that forage characteristics which may affect utilization of these plants are: the content of digestible CWC, the content of indigestible CWC, the structure of CWC and the concentration of ash in plants.

Results of phytochemical screening in Table (5) indicated that $H$. elegans, $L$. raetam and $P$. harmala contained highly intense at alkaloids, however, $K$. indica, A. monosperma, T. mannifera and T. hirsuta were free. Some of alkaloids have a bitter taste to animals and exhibit pharmaceutical action as well as forming drugs such as morphin, codin and atrobin. There were negative correlation exists between total alkaloid content and plants utilization (Marten, 1973).

Table (5): Phytochemical screening of some shrubs grown in Egyptian desert.

\begin{tabular}{|c|c|c|c|c|c|c|}
\hline \multirow{2}{*}{ Items } & \multicolumn{6}{|c|}{ Phytochemical Screening } \\
\hline & Saponins & Alkaloids & Flavonoids & Sterols & Tannins & coumarins \\
\hline Kochia indica & + & - & + & + & - & - \\
\hline Suaeda vera & - & + & + & + & - & + \\
\hline Artemisia monosperma & - & - & +++ & + & - & ++ \\
\hline Hammada elegans & + & +++ & - & ++ & - & ++ \\
\hline Atriplex halims & + & + & + & - & + & + \\
\hline Thymalaea hirsuta & - & - & ++ & ++ & - & - \\
\hline Tamarix mannifera & - & - & ++ & ++ & +++ & + \\
\hline $\begin{array}{l}\text { Halocnemum } \\
\text { strobiclaceum }\end{array}$ & ++ & + & + & + & + & + \\
\hline Zygophillum album & +++ & + & ++ & + & + & - \\
\hline Lygos raetam & - & +++ & + & + & - & ++ \\
\hline Peganum harmala & + & +++ & + & + & - & - \\
\hline
\end{tabular}

+ slightly detected - non detected

Z.album, T. hirsuta and T. mannifera had a moderately intense of flavonoids. The flavonoids substances as whole are relatively harmless in nutrition, although they may contribute to bitter taste and some of them act as animal toxins.

The highest levels of saponins are showed in Z.album and $H$. strobilaceum, however most of evaluated shrubs had low levels. In ruminants, saponins were implicated in causing bloat and inhibit microbial fermentation and synthesis as well as formation calcium salt of saponins in and around the bile duct, also saponins have negative effect on growth rate in livestock (Price et al., 1987).

The highly concentration of tannins was found in $T$. mannifera, however, most of tested shrubs had slightly or non detected tannins. Tannins reduce voluntary feed intake and reduce digestibility of protein and carbohydrate by inhibiting digestive enzymes and by altering the permeability of the gut wall (Reed et al., 1990). Tannins may reduce bacterial enzymes and/ or forming indigestible complex with cell wall carbohydrates (Tanner et al., 1990). 


\section{AbdEI-Rahman,H.H. et al.}

\section{Conclusions}

Feeding halophytes is a feasible solution to minimize the problem of feed shortage in developing countries, where desert represent high percentage of the total area. Therefore, proper range management and utilization of halophytes as an animal feed should have the priority of the development plane. Efforts have been directed to identify the most critical problems of livestock nutrition on native range lands and the prospects for better solution.

The present study suggested that the nutritive potential of tested halophytic plants varied from species to other. Moreover, the native range lands as the principle feed resources considerably fluctuate in biomass production; palatability and nutritive value from season to reason and from area to area due to many factors. The green biomass of halophytes may not sustain the nutritional requirements of animals, practically during dry season. Thus supplementary feeding should be practiced in an economic way. In this respect, it is recommended to improve the native range species as well as to cultivate some of high potential shrubs.

\section{REFERENCES}

Abd El-Rahman, H.H. (2003). Constraints and possibilities for their alleviation to improve utilization of desert natural range plants for grazing ruminants. Ph. D. Thesis, Fac. of Agric. Cairo Univ.

Allison, D.W. and Osbourn, D.F. (1970). The cellulose-lignin complex in forages and its relationship to forage nutritive value. J. Agric. Sci. Comb. 74:23.

A.O.A.C. (1996). Association of Official Analysis Chemists, Official Methods of Analysis (16 th Ed.) Washington, D.C, USA

Barnes, T.G.; Varner, L.W.; Balnkenship, L.H.; Fillinger, T.J. and Heineman, S.C. (1990). Macro and tracemineral content of selected south taxas deer forages. J. Range Manage. 43, 220-223.

Carrilla-Soto, M.A.; Nevarez- Carrasco, G.; Ramirez-Lozana, R.G; NunezGonzalez, A.; Garcia-Diaz, G. and Juarez-Reyes, A.S. (2004). Mineral profile of diets consumed by range Spanish goats in shrubland of North Mexico. Afr.J.Anim. Sci. Suppl. 1,117-119.

Chapman, V.J. (1974). Salt marches and salt desert of the world. In: R.J. Reinold W.H. Queen (eds.) Ecology of halophyte., Academic press, New York. Pp. 3-19.

Fagg, C. W. and Stewart, J. L. (1994). The value of Acacia and Prosopis in arid and semi-arid environments. J. Arid Environ. 27: 3-25.

Gihad, E.A.; Shoukry, M.M.; Hanafy, M. A.; Mansour, A.F. and Abd ElRahman, H.H. (2003). Secondary compounds affect intake by range sheep and goats. Egyt. J. Nutr. And feeds 6 (Special Issue): 1301.

Goering, H.K. and Van Soest, P.T. (1970). Forage fiber analysis and some application. Agri. Hand book No. 375. USDAARS. Washington, D.C., P. 20402. 
James, W.O. and Edwaed, G. P. (1994). Global distribution and potential for halophytes. Proceeding of the international workshop on halophytes for reclamation of saline wasteland and as a resource for livestock (problem and prospect) Niroby, Kenya 24-27 November.

Kingharm, A,D. and Evans, F.J. (1974). Planta Medica 26: 150. cited in Mohamed, 1996.

Marten, G.C. (1973). In: Anti-quality component of forages p. Is. J. Crop Sci. Soc. Am., Madison, WI.

Moya-Rodriguez, R.J.G.; Ranivez, R.G.; Foroughbakhch, R.; Hauad, L. and Gonzalez, H. (2002). Variation estacional de minerals or las hojas de ocho especies arbustiva. Ciencia UANL., Universidad Autonoma de Nuevo Leon, Mexico pp. 59-65.

Mohamed, M.I. (1996). Studies on desert roughages on camels and small ruminants nutrition. Ph.D. Thesis, Fac. of Agric. Cairo Univ., Egypt.

Norris, K.H.; Basnes, R.F.; Moore, J.E. and Shenk, J.S. (1976). Predicting forage quality by infrared reflectance spectroscopy. J. Anim. Sci. 43: 889.

Price, K.R.; Johanson, I.T. and Fenwick, G.R. (1987). The chemistry and biological significance of saponins in foods and feeding stuffs. G: Tical Re. In J. Food Sci. and Nut. 26.1:27.135.

Ramirez, R.G. (1999). Feed resources and feeding techniques of small ruminants under extensive management conditions. Small Rumin. Res. $34,215-230$.

Ramirez, R.G.; Haenlein, G.F.W.; Nunez-Gonzalez, M.A. (2001). Seasonal variation of macro and trace mineral contents in 14 browse species that grow in north eastern Mexico. Small Rumin. Res. 39,153-159.

Ramirez-Orduna, R.; Ramirez, R.G.; Gonzalez Rodriguez, H. and Haenlein, G.F.W. (2005). Mineral content of browse species from Baja California Sur, Mexico. Small Rumin. Res. 57, 1-10.

Ramirez-Orduna, R.; Ramirez, R.G.; Ramirez-Ordana, J.M.; CepedaPalacios, R. and Avila-Sandoval, J.M. (1998). Seasonal variation in nutrient content of shrubs from Baja California Sur, Mexico. For. Farm Community Tree Res. Rep. 3, 13-17.

Reed, J.D., Soller, H. and Wood Word. A. (1990). Fooder tree and straw diets for sheep: Intake, growth, digestibility and the effects of phenolies or nitrogen utilization J. Anim. Feed Sci. and Techn. 30.39.

Schmidt, N. K. (1964). The camel. In: Desert animal: Physiological problems of heat and water. Oxford, Cleremdon press.

Tanner, J.C.; Reed J.D. and Owen, E. (1990). The nutritive value of fruits (pods with seeds) from four Acacia. Spp. Compared with Nong (Guizotia abssinica) meal as supplements of maize stover for Ethiopian high land sheep, J. Anim. Prod. 51.157.

Tilley, J. M.A. and terry, R.A. (1963): A two-stage technique for in vitro digestion of forage crops. J. Brit Crassl. Soc., 18: 101.

Vogel, A.I. (1956). Practical organic chemistry. 3rd ed. P. 453, Longman's London.

Waghorn, G.C. and Shelton, I.D. (1997). Effect of condensed tannins in Lotus cornicufatus on the nutritive value of pasture for sheep. J.Agri: Sci. 128: 365-372. 


\section{AbdEI-Rahman,H.H. et al.}

Wall, M.E.; Krieder, M.M.; Krewsa, C.F.; Eddy, C.R.; William, J.; Caral, D. S. and Centry, H.S. (1954) J. Aner. Pharn. Assoc. U3: 1. Cited in "Abd ElAziz, H.M. 1983. Chemical investigation of certain Euphorbia species. M. Sc. Thesis, Fac. of Sci. Cairo Univ."

Wardeh, M.F. 1982. Models for estimating energy and protein utilization of feeds. Ph.D. Disertation. Utah State University, Logan, Utah. USA.

Wardeh, M.F.; Douze, M. and Duld-Mostafa, M.M. (1990) The nutritive value of plant species eaten by camels. Proc. Int. Con. Camel Prod. and Impr. Tobruk. Libia. December 10-1990.

Willstatter, R. (1914). Ber, 47, 2831. cited in "Abd El-Aziz, H.M. 1983. Chemical investigation of certain Euphorbia species M. Sc. Thesis, Fac. of Sci. Cairo Univ.

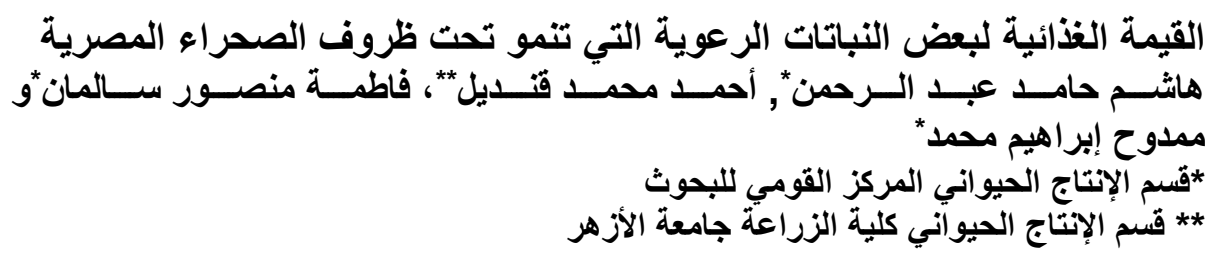

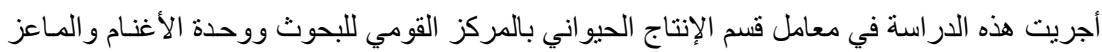
بمزر عة النوبارية و التابعة لقسم الإنتاج الحيو اني.

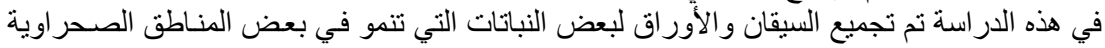

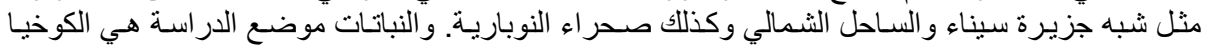

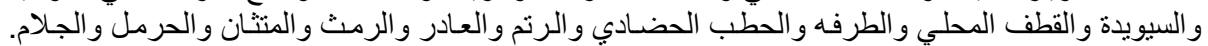

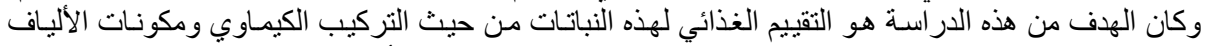

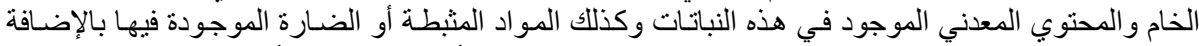

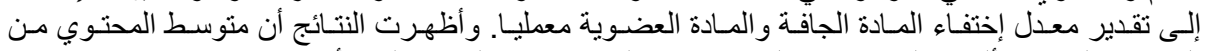

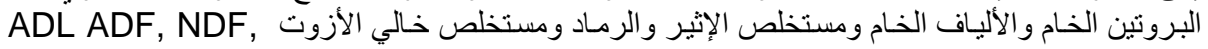

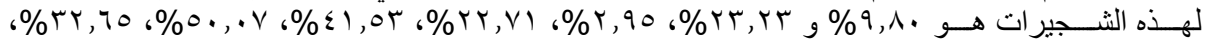

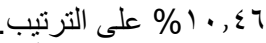

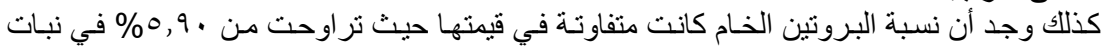

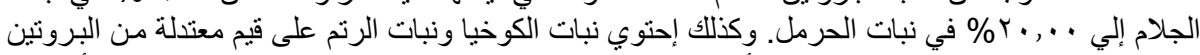

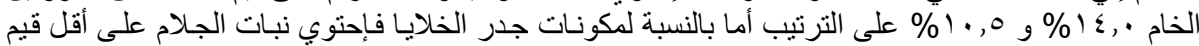

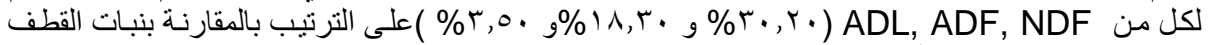

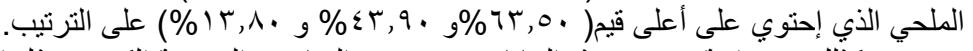

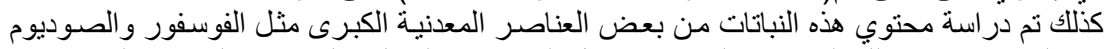

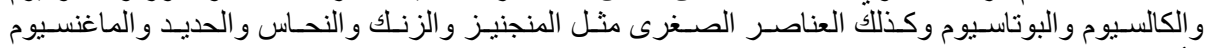

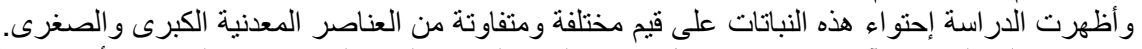

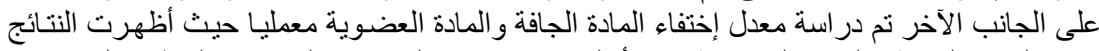

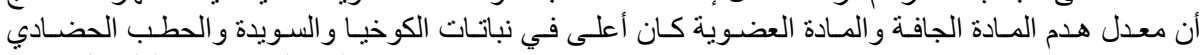

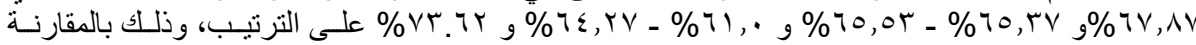

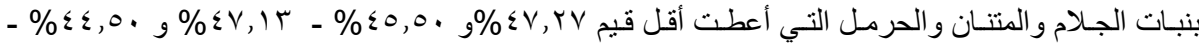
年

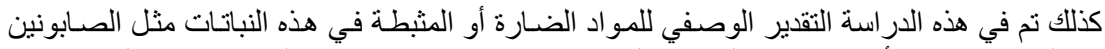

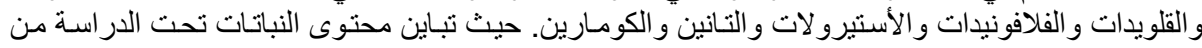

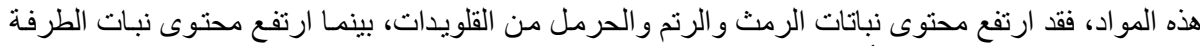
من الثانين، وكان نبات الجلام أكثر النباتات احتو اءواء على الصابونين. 